\title{
Insights into the pH-dependent, extracellular sucrose utilization and concomitant levan formation by Gluconobacter albidus TMW 2.1191
}

\author{
Frank Jakob • Clara Gebrande $\cdot$ Regina M. Bichler $\cdot$ Rudi F. Vogel
}

Received: 18 December 2019/Accepted: 20 February 2020/Published online: 4 March 2020

(C) The Author(s) 2020

\begin{abstract}
Many bacteria and archaea produce the polydisperse fructose polymer levan from sucrose upon biofilm formation via extracellular levansucrases (EC 2.4.1.10). We have investigated levansucraserelease and -activities as well as molecular size of the levan formed by the acetic acid bacterium Gluconobacter albidus TMW 2.1191 at varying environmental $\mathrm{pH}$ conditions to obtain insight in the ecological role of its constitutively expressed levansucrase and the produced levan. A buffer system was established enabling the recovery of levansucrasecontaining supernatants from preincubated cell suspensions at $\mathrm{pH}$ 4.3- $\mathrm{pH}$ 5.7. The enzyme solutions were used to produce levans at different $\mathrm{pH}$ values and sucrose concentrations. Finally, the amounts and size distributions of the produced levans as well as the corresponding levansucrase activities were determined and correlated with each other. The data revealed that the levansucrase was released into the environment independently of its substrate sucrose, and that more levansucrase was released at $\mathrm{pH} \geq 5$.0.
\end{abstract}

Electronic supplementary material The online version of this article (https://doi.org/10.1007/s10482-020-01397-3) contains supplementary material, which is available to authorized users.

F. Jakob $(\varangle)$ · C. Gebrande · R. M. Bichler · R. F. Vogel Lehrstuhl für Technische Mikrobiologie, Technische Universität München, Gregor-Mendel-Straße 4, 85354 Freising, Germany

e-mail: frank.jakob@wzw.tum.de
The glucose release and formation of high molecular weight levans $(>3.5 \mathrm{kDa}$ ) from $0.1 \mathrm{M}$ initial sucrose was comparable between $\mathrm{pH} \sim 4.3-5.7$ using equal amounts of released levansucrase. Hence, this type of levansucrase appears to be structurally adapted to changes in the extracellular $\mathrm{pH}$ and to exhibit a similar total activity over a wide acidic $\mathrm{pH}$ range, while it produced higher amounts of larger levan molecules at higher production $\mathrm{pH}$ and sucrose concentrations. These findings indicate the physiological adaptation of G. albidus TMW 2.1191 to efficient colonisation of sucrose-rich habitats via released levansucrases despite changing extracellular $\mathrm{pH}$ conditions in course of acid formation.

Keywords Gluconobacter $\cdot$ Sucrose $\cdot \mathrm{pH}$. Levansucrase · Levan

\section{Introduction}

Bacterial levansucrases (EC 2.4.1.10) are extracellular enzymes that catalyze the synthesis of the $\beta$-2,6-linked fructose polymer levan. These enzymes use the energy of the glycosidic bond of their substrate sucrose for fructose polymerization while glucose is continuously released. If water is used as acceptor instead of a growing fructose polymer chain, sucrose is hydrolyzed by levansucrases (Öner et al. 2016; VelázquezHernández et al. 2009). Moreover, some levansucrases 
exhibit an intrinsic exolevanase activity leading to the degradation of the levan molecules (Méndez-Lorenzo et al. 2015). The released glucose (and fructose from potential hydrolysis reactions) can be used for metabolic purposes. Levansucrases are abundant among bacteria and archaea (Öner et al. 2016), enable sucrose utilization (Arrieta et al. 1996) and contribute to biofilm formation of plant-associated Bacillus subtilis, Erwinia amylovora or Pseudomonas syringae (Dogsa et al. 2013; Koczan et al. 2009; Laue et al. 2006). In sucrose-containing foods like (sweetened) sourdough breads, kefir or natto, levan is produced by indigenous starter cultures, e.g. Lactobacillus spp., Gluconobacter spp. or Bacillus subtilis (Natto) (Fels et al. 2018; Jakob et al. 2012a; Korakli et al. 2003; Semjonovs et al. 2016; Shih et al. 2005; Tieking et al. 2005; Tieking and Gänzle 2005; Xu et al. 2006). The macromolecular or rather hydrocolloid properties of levan in aqueous solution mainly depend on its molecular weight and can be additionally influenced by its branching degree (at position $\mathrm{Ol}$ ) and polydispersity (Hundschell et al. 2019, 2020; Jakob et al. 2012b, 2013). However, it is unknown, which and if a certain amount, specific size and composition of levan is essential for survival or assertiveness of the producer strains. As levansucrases are active in the extracellular environment, they are exposed to multiple continuously changing reaction conditions, e.g. in terms of the available substrate concentration, $\mathrm{pH}$ or temperature. Therefore and because of the great diversity of levansucrases from diverse microbial sources (Velázquez-Hernández et al. 2009), levan can be mainly composed of short-chain fructooligosaccharides (degree of polymerization of 3-10) (Támbara et al. 1999), or in other cases predominantly of high molecular weight molecules exhibiting an averaged molecular weight $>10^{8}$ Da (Jakob et al. 2013; UaArak et al. 2017a). Levansucrases are abundant in acetic acid bacteria (Acetobacteraceae) and strictly present in one gene copy in all strains of different species within the genus Gluconobacter (Jakob et al. 2019), which typically occur in sugary, sucrose-rich environments and are specialized in glucose oxidation to gluconic acid via membrane-bound dehydrogenases (Deppenmeier and Ehrenreich 2009). Nothing is still known about the release of Gluconobacter levansucrases and if or to which extent their extracellular activity and product specificity are influenced by changing $\mathrm{pH}$ conditions in course of acid formation from e.g. naturally present sucrose. As previous studies revealed that the $\mathrm{pH}$ is crucial for the hydrocolloid properties, amount and the size distributions of the globular high molecular weight levan molecules produced by the water-kefir isolate Gluconobacter albidus TWM 2.1191 (Hundschell et al. 2020; Ua-Arak et al. 2017a), we wanted to investigate its possible physiological adaptation to extracellular sucrose consumption via released levansucrases despite changing $\mathrm{pH}$ conditions. For this purpose, a buffer system for the recovery of its levansucrase at different $\mathrm{pH}$ values and for the cell-free production of levan at different $\mathrm{pH}$ values and sucrose concentrations was established. The obtained data about levan amounts and sizes should finally be correlated with the volumetric activities of the levansucrases to get deeper insight into the ecological role of the extracellular levansucrase and the formed levan.

\section{Materials and methods}

Levansucrase recovery and levan production at different $\mathrm{pH}$ and sucrose concentrations

Gluconobacter (G.) albidus TMW 2.1191 isolated from water-kefir (Jakob et al. 2012a; Ua-Arak et al. 2017a) was incubated in Erlenmeyer flasks, which were filled with $10 \%$ liquid medium relative to the total volume of the flask to facilitate aerobic growth on a rotary shaker (200 rpm). A general overview of the experimental steps for levansucrase recovery and levan production at different $\mathrm{pH}$ is depicted in Fig. 1. The NaG-medium used for precultivation of G. albidus contained $20 \mathrm{~g} / \mathrm{L}$ sodium gluconate, $3 \mathrm{~g} / \mathrm{L}$ yeast extract, $2 \mathrm{~g} / \mathrm{L}$ peptone, $3 \mathrm{~g} / \mathrm{L}$ glycerol, $10 \mathrm{~g} / \mathrm{L}$ mannitol, $3 \mathrm{~g} / \mathrm{L}$ glucose (initial $\mathrm{pH}$ adjusted to 6.0). The optical densities (ODs) of the fermented $\mathrm{NaG}$ media were determined at $600 \mathrm{~nm}$ in a Novaspec Plus spectrophotometer (Amersham Biosciences, Germany). The number of cells in liquid culture media was determined as colony forming units (CFU) on solid $\mathrm{NaG}$ agar $(15 \mathrm{~g} / \mathrm{L})$ media in duplicates. Harvested cells from liquid cultivations in $\mathrm{NaG}$ medium were resuspended in $0.1 \mathrm{M}$ sodium-acetate $(\mathrm{Na}-\mathrm{Ac})$ buffers, which had been adjusted to five different $\mathrm{pH}$ values (4.3-5.7). For investigation of the impact of the levansucrase-release $\mathrm{pH}$ on levan production at different $\mathrm{pH}$ (3.1), the levansucrase-containing 


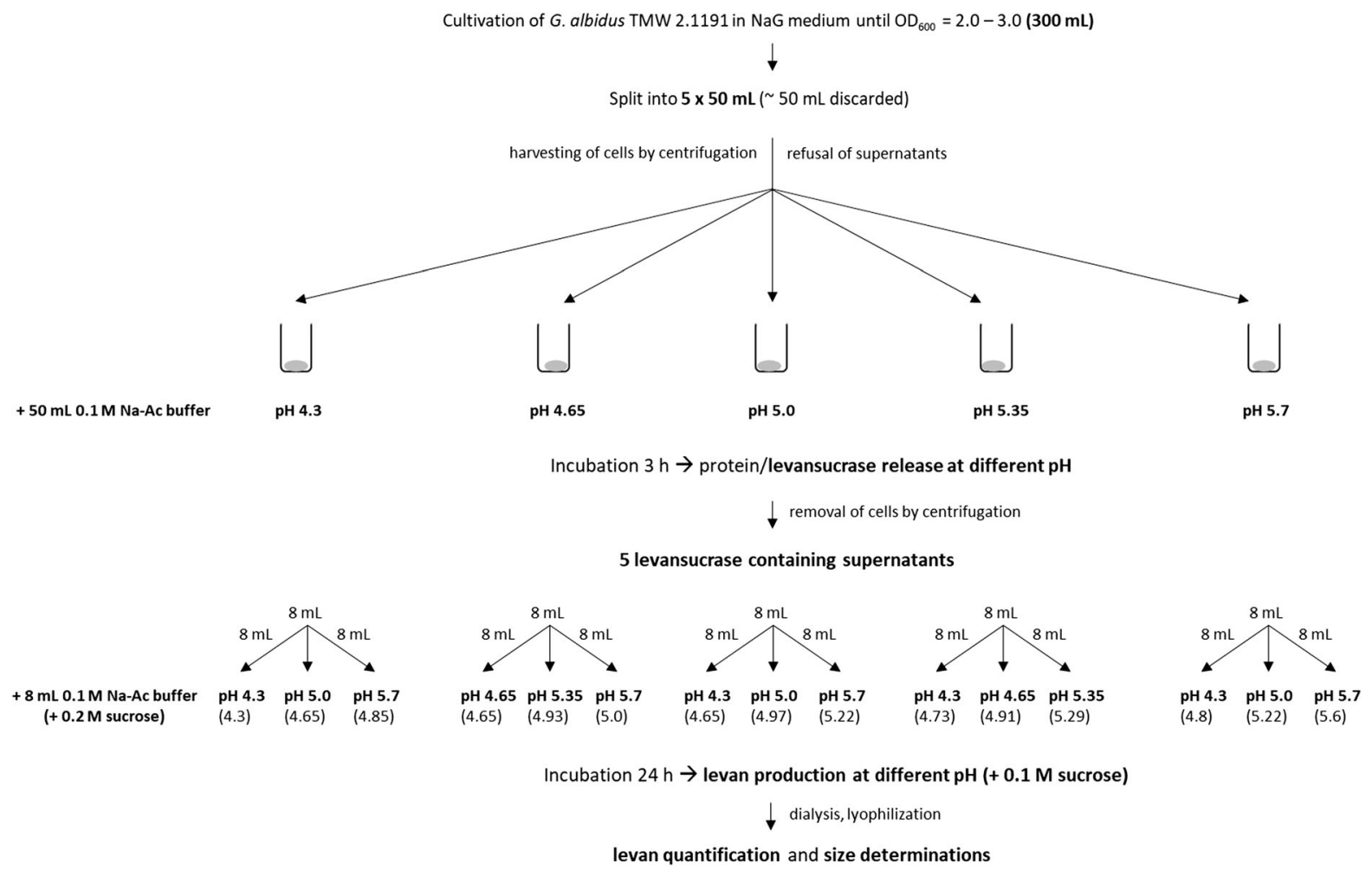

Fig. 1 Workflow for the recovery of levansucrase containing supernatants and for the subsequent levan production at different $\mathrm{pH}$ (chapter 3.2). The $\mathrm{pH}$ values in brackets indicate the determined final production $\mathrm{pH}$ after mixing of the respectively used buffers. Three independently grown cell cultures $(300 \mathrm{~mL}$; OD 2.2, 2.58, 2.84) were prepared and handled as depicted. The obtained results about amounts and sizes of the recovered levans as well as contained volumetric levansucrase activities (in total 15 samples per cell culture: 5 release $\mathrm{pH} \times 3$ production $\mathrm{pH}$ ) were finally compared among each other (Fig. 3 and Supplementary File 1)

containing four different sucrose concentrations (0.1/ $0.2 / 0.4 / 0.8 \mathrm{M}$ ). For levan production, the solutions were statically incubated for $24 \mathrm{~h}$ at $30^{\circ} \mathrm{C}$ in both experimental series. The levan samples were dialyzed (MWCO: $3.5 \mathrm{kDa}$ ) against $\mathrm{ddH}_{2} \mathrm{O}\left(4{ }^{\circ} \mathrm{C} ; 48 \mathrm{~h}\right.$ ) for removal of sugars and fructooligosaccharides $<3.5 \mathrm{kDa}$, lyophilized and weighed.

Separation and size determinations of levans by AF4-MALLS

The radii distributions of the produced high molecular weight levans were determined by asymmetric flow field-flow fractionation (AF4; Eclipse Dualtec, Wyatt Technology, USA) coupled to multi-angle laser light scattering (MALLS) (Dawn EOS: levans produced at different $\mathrm{pH}$ values; DAWN Heleos II: levans produced at different sucrose concentrations; Wyatt 
Technology, USA). The lyophilized levans were dissolved in $\mathrm{ddH}_{2} \mathrm{O}$ to a final concentration of $0.1 \mathrm{mg} / \mathrm{mL} .100 \mu \mathrm{l}$ of the respective sample $(10 \mu \mathrm{g})$ were then injected into the separation channel, equipped with a $10 \mathrm{kDa}$ cellulose membrane (Nadir regenerated cellulose). Levan separations were performed using a detector-flow rate of $1 \mathrm{~mL} / \mathrm{min}$ and a cross-flow gradient of 3 to $0.1 \mathrm{~mL} / \mathrm{min}$ over $15 \mathrm{~min}$, followed by $15 \mathrm{~min}$ of a steady cross flow of $0.1 \mathrm{~mL} /$ min. The obtained chromatograms were analyzed with the software ASTRA 6 (Wyatt Technologies, Germany) using the integrated particle mode and the sphere model. The accuracy and reproducibility of levan separations on the used cellulose membranes was randomly checked by either remeasuring of levan samples or measuring of bovine serum albumin (in this case injection and separation of $50 \mu \mathrm{g}$ using a constant crossflow of $5 \mathrm{~mL} / \mathrm{min}$ for $25 \mathrm{~min}$ ).

Protein separation, visualisation and identification

For separation of proteins recovered in buffers, SDS gels $(10 \%)$ were prepared using the materials of a Mini-PROTEAN set (BioRad, Germany). Silver and Coomassie stainings were performed for visualization of proteins. Protein concentrations were determined in triplicate in 96 well plates using the Bradford assay (Sigma Aldrich, Germany). The buffers used for levansucrase release ( $8 \mathrm{~mL}$; Fig. 1) were concentrated

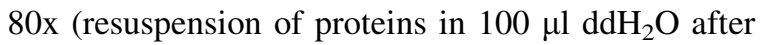
lyophilization of buffers) before SDS-PAGE (and Bradford analysis), as no bands could be visualized without concentration of the samples. For verification of the levansucrase, the stained protein of the expected size $(\sim 48 \mathrm{kDa})$ was excised from the SDS gel and sent to the "Zentrallabor für Proteinanalytik" (ZfP, Ludwig-Maximilians-Universität München). Upon tryptic digestion and modification of the respective proteins for proper separation and mass spectra generation by LC-MS/MS, the obtained mass spectra were compared with in silico tryptically digested proteins of the domain Eubacteria (deposited at NCBI) using the Matrix Science Mascot software (Perkins et al. 1999). Additionally, the "Mascot generic format (.mgf) formatted" files derived from LC-MS/MS analysis, were processed to peptide sequences with PepNovo (Frank and Pevzner 2005; Frank et al. 2005, 2007) and "blasted" against available proteoms of $\mathrm{AAB}$, as also described by Behr et al. (Behr et al. 2007), to confirm the obtained Mascot search results.

\section{Determination of levansucrase activities}

The mean activities ( $24 \mathrm{~h}$ ) of the native levansucrases used for production and determination of sizes of levans were calculated by determination of enzymatically released sugars via HPLC analysis using a Rezex RPM ion-exclusion column (Phenomenex, Germany) coupled to a refractive index (RI) detector (Gynkotek, Germany). The water flow (mobile phase) was kept constant at $0.6 \mathrm{~mL} / \mathrm{min}$ during each run, separations were performed at $85^{\circ} \mathrm{C}$. Calibration curves were established using the standards glucose and fructose in different concentrations (1-100 mM). The released glucose was used for calculation of the overall activity, while the detected fructose was (additionally) used for calculation of the hydrolysis (concentration fructose) and transfructosylation activities (concentration glucose-concentration fructose) (Tieking et al. 2005). Volumetric activities of levansucrases are expressed in Units (U), which are defined as $\mu \mathrm{mol} / \mathrm{mL}$ (protein sample) $*$ min. In doing so it is assumed that no other sucrose, glucose and fructose converting activities affecting the activity calculations were present in the crude extracts containing the natively released or heterologously expressed (below) levansucrase.

For comparison of the kinetics of the G. albidus TMW 2.1191 levansucrase at different $\mathrm{pH}$ and sucrose concentrations (Supplementary File 2), the cloned levansucrase gene was heterologously expressed in Escherichia (E.) coli Top 10 (Jakob et al. 2012a) by induction with arabinose $\left(1 \mathrm{mM}, 25^{\circ} \mathrm{C}, \mathrm{o} / \mathrm{n}, 200 \mathrm{rpm}\right)$ according to the instructions of the pBAD cloning/expression manual (Invitrogen, Germany). After harvesting of the cells by centrifugation $(30 \mathrm{~mL}$ culture; $10 \mathrm{~min} ; 5000 \times \mathrm{g}$ ), the cells were resuspended in $1 \mathrm{~mL}$ $\mathrm{Na}-\mathrm{Ac}$ buffer ( $\mathrm{pH}$ 5), as preliminary experiments had revealed that the recombinant levansucrase drastically lost its activity at $\mathrm{pH} 7$ (compare also supplementary File 2). The cells were subsequently lysed by sonication and the insoluble debris was removed by centrifugation $(10,000 \times g)$. For activity assays, the obtained levansucrase-containing supernatants were again diluted 1:30 in 0.1 M sodium acetate buffer $(\mathrm{pH}$ 5.0) and directly applied, as the enzyme could not be purified at $\mathrm{pH} 5.0$ by Ni-NTA affinity 
chromatography according to the manufacturers' instructions (performed at alkaline $\mathrm{pH}$ (Spriestersbach et al. 2015)). Non-induced E. coli Top 10 cultures/ lysates thus served as control to exclude any intrinsic sucrose related activities in the E. coli lysates. A reaction assay consisting of $100 \mu \mathrm{l}$ sucrose $(0.025 \mathrm{M}-$ $1.6 \mathrm{M}), 50 \mu \mathrm{l} 0.4 \mathrm{M}$ citric acid/sodium citrate buffer (pH 3.0-4.0) or $\mathrm{Na}-\mathrm{Ac}$ buffer $(\mathrm{pH} 4.3-5.7)$ or $\mathrm{NaH}_{2} \mathrm{PO}_{4} / \mathrm{Na}_{2} \mathrm{HPO}_{4}$ buffer ( $\mathrm{pH}$ 6.0-7.0), $45 \mu \mathrm{lddH} \mathrm{H}_{2} \mathrm{O}$ and $5 \mu \mathrm{l}$ of the enzyme dilution was incubated in a water bath at $30{ }^{\circ} \mathrm{C}$ for $1 \mathrm{~h}$. The same volume $(200 \mu \mathrm{l})$ of $0.25 \mathrm{M} \mathrm{NaOH}$ was then added and mixed thoroughly to stop the enzymatic reaction. $10 \mu \mathrm{l}$ of each preassay sample was transferred in triplicates to a Microtest plate (96 wells, Sarstedt) and mixed with $200 \mu \mathrm{ldd} \mathrm{d}_{2} \mathrm{O}, 10 \mu \mathrm{l}$ buffer 1 and $10 \mu \mathrm{l}$ buffer 2 from the D-Fructose/D-Glucose Assay Kit (Megazyme, Ireland). After $3 \mathrm{~min}$ the initial absorbance was measured with a FLUOstar Omega microplate reader (BMG Labtech, Germany). $10 \mu \mathrm{l}$ of solution 3 (included in kit) were then added, the microplate was shaken for further $20 \mathrm{~s}$ and the second absorbance was measured after $8 \mathrm{~min}$. Afterwards, $10 \mu \mathrm{l}$ of solution 4 were added and the microplate was again shaken for $20 \mathrm{~s}$. The final absorbance was measured after $10 \mathrm{~min}$. The glucose and fructose concentrations were calculated via the law of Lambert-Beer, respectively. For pH 3.0 and $\mathrm{pH} 3.5$, sucrose hydrolysis was observed in the control samples (without enzyme solution), most likely due to spontaneous acidic hydrolysis at low $\mathrm{pH}$. In these cases, additional controls were applied for all substrate concentrations and included in the levansucrase activity calculations.

\section{Statistical analysis}

Data depicted in Figs. 3, 5 and Supplementary File 2 are expressed as mean values including standard deviations (SD) derived from three independent experiments, respectively. The origin of these data is further specified in the respective results sections and figure captions. The bilateral homoscedastic $t$ test was used to describe significant differences at 5\% significance level $(p<0.05)$, respectively.

\section{Results}

Analysis of buffer supernatants recovered at different $\mathrm{pH}$

The buffer supernatants obtained after $3 \mathrm{~h}$ of incubation at $\mathrm{pH} 4.3,4.65,5.0,5.35$ and 5.7 (Fig. 1) were analyzed regarding their respective protein contents and the presence of the levansucrase. The protein amount was always below the detection limit of the used assay $(0.1 \mathrm{mg} / \mathrm{mL})$, even if the buffer supernatants were concentrated $80 \mathrm{x}$ before analysis $(8 \mathrm{~mL} \rightarrow 0.1 \mathrm{~mL})$. Therefore, a total protein amount $<0.01 \mathrm{mg} / \mathrm{mL}$ was present in all samples. However, after $80 \times$ concentration of the samples and subsequent SDS-PAGE, the extracellular proteins could be visualized by silver staining. On the contrary, no proteins could be visualized by Coomassie staining at any tested condition. Similar profiles were detected at the tested $\mathrm{pH}$ values 4.3/4.65/5.0. Few differences could be observed in regard to the presence of certain proteins at 5.35 and 5.7 (Fig. 2). The levansucrase monomer exhibiting a putative size of $\sim 48 \mathrm{kDa}$ (NCBI accession number: AQS91558) was cut out of the gel ( $\mathrm{pH}$ 5.7) and verified by mass-based peptide sequencing as described previously by Jakob (2014).

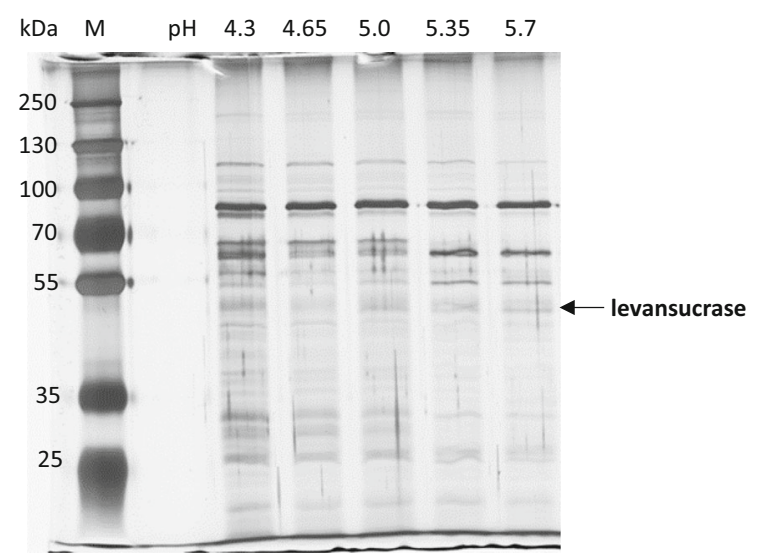

Fig. 2 SDS-PAGE of levansucrase containing supernatants recovered at $\mathrm{pH} 4.3,4.65,5.0,5.35$ and 5.7. M: marker 
Amounts and radii distributions of levans produced at different $\mathrm{pH}$ initially used for levansucrase recovery

The collected enzyme-containing supernatants were used to produce levan at $0.1 \mathrm{M}$ sucrose and three different $\mathrm{pH}$ values per release $\mathrm{pH}$ (Fig. 1). This approach was repeated in triplicate using three main cultures (300 mL) of G. albidus TMW 2.1191 grown to $\mathrm{OD}_{600}=2.2,2.58,2.84$, respectively, which were split $(5 \times 50 \mathrm{~mL})$ for enzyme release at different $\mathrm{pH}$, respectively (Fig. 1). The CFU/mL increased with increasing OD (OD 2.2: $8.5 \pm 0.25 * 10^{8}$; OD 2.58: $1.05 \pm 0.24 * 10^{9}$; OD 2.84: $1.17 \pm 0.18 * 10^{9}$ ). After levan quantification and determination of the respective overall, transfructosylation and hydrolysis activities it was observed, that the amounts of isolated levan and the corresponding activities were in a similar range per release $\mathrm{pH}$ (Supplementary File 1A-F). Therefore, it could be assumed that the final production $\mathrm{pH}$ was not decisive within the tested $\mathrm{pH}$ range, if the same enzyme solution recovered at a certain $\mathrm{pH}$ condition was used for levan production. The three values obtained per release $\mathrm{pH}$ were thus averaged to compare the impact of the initial cell density and the release $\mathrm{pH}$ on the levan formation (Fig. 3).

The isolated levan amounts were significantly higher $(p<0.05)$, if a higher initial cell density had been applied (Fig. 3A). Moreover, the levan amounts significantly increased with rising production $\mathrm{pH}$, respectively, with two exceptions at OD $2.2(\mathrm{pH} 4.35$ compared to $\mathrm{pH} 4.65$ and $\mathrm{pH} 5.35$ compared to $\mathrm{pH}$ $5.7 \rightarrow p>0.05$ ). A similar trend was observed upon comparison of the calculated volumetric activities, which were accordingly higher, if a higher cell density and release $\mathrm{pH}$ had been initially applied (Fig. 3B-D). The size distributions of the levan molecules were shifted per release $\mathrm{pH}$, even if they had been produced in comparable amounts at different $\mathrm{pH}$ values using constant protein amounts (Fig. 4). The respective peak maxima, which are representative for the majority of molecules exhibiting a certain size, were generally shifted to higher geometric radii, if the levan had been produced at higher $\mathrm{pH}$ (Fig. 4A-F).

Amounts and radii distributions of levans produced at different $\mathrm{pH}$ and sucrose concentrations

Additional experiments using the heterologously expressed levansucrase of G. albidus TMW 2.1191 revealed that the enzyme exhibits comparable activities and Michaelis-Menten kinetics within a broad $\mathrm{pH}$ range (Supplementary File 2). Therefore, the influence of the sucrose concentration on the produced levan amounts and sizes was additionally investigated. For this purpose, three additional cell cultures (each $300 \mathrm{~mL}$; OD 2.63: $1.33 \pm 0.16 \mathrm{CFU} / \mathrm{mL}$, OD 2.77: $1.42 \pm 0.05 \mathrm{CFU} / \mathrm{mL}$, OD 3.0: $1.575 \pm 0.025 *$ $10^{9} \mathrm{CFU} / \mathrm{mL}$ ) were used for recovery of levansucrase-containing supernatants at $\mathrm{pH} \mathrm{4.3,} \mathrm{4.65,} \mathrm{5.0,}$ 5.35 and 5.7 according to the workflow depicted in Fig. 1. After removal of cells, the supernatants were used to produce levan at four different sucrose concentrations $(0.05,0.1,0.2,0.4 \mathrm{M})$ and at the $\mathrm{pH}$ of levansucrase release, respectively (20 samples per cell culture). The produced levans were quantified once per cell culture and averaged among the three cell cultures (Fig. 5A). Moreover, the overall activities were determined in all samples (Fig. 5B). Except for $\mathrm{pH} 4.3$, significant higher amounts of levan were isolated per release $\mathrm{pH}$, if a higher initial sucrose concentration had been applied (Fig. 5A). This finding was confirmed via calculation of the respective overall activities, which increased per release $\mathrm{pH}$ using higher sucrose concentrations (Fig. 5B). The levan amounts significantly increased with rising release $\mathrm{pH}$ of the levansucrase using equal initial sucrose concentrations between $\mathrm{pH}$ 4.3/4.65 and $\mathrm{pH}$ 4.65/5.0 (Fig. 5C). Between $\mathrm{pH} 4.65 / 5.0$ this was also confirmed by the calculated overall activities (Fig. 5D). The levan sizes slightly increased per release $\mathrm{pH}$ using higher initial sucrose concentrations (Fig. 6A-E). Moreover, the levan sizes increased with rising release $\mathrm{pH}$ using equal initial sucrose concentrations (Fig. 6F-I). 

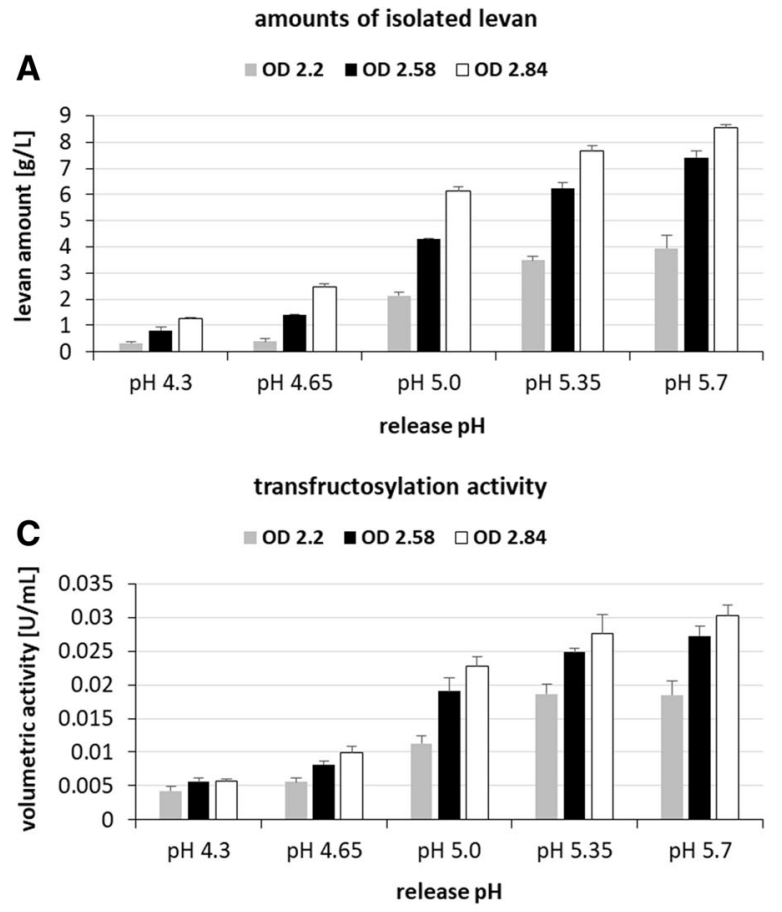

Fig. 3 Produced levan amounts (A) and the corresponding volumetric overall (B), transfructosylation $(\mathbf{C})$ and hydrolysis (D) activities determined after $24 \mathrm{~h}$ of levan production at different $\mathrm{pH}$ using three different main cultures (OD 2.2, OD
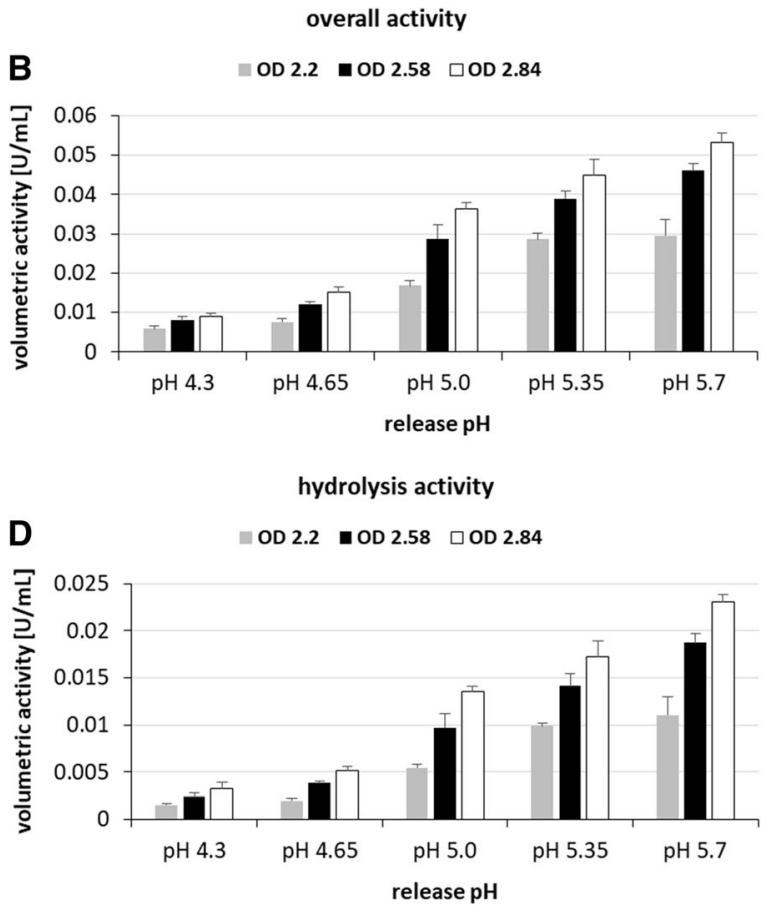

2.58, OD 2.84). Mean values $(\mathrm{n}=3)$ including standard deviations (SD) were calculated from three different production $\mathrm{pH}$ per release $\mathrm{pH} /$ used cell culture (Supplementary File 1), respectively
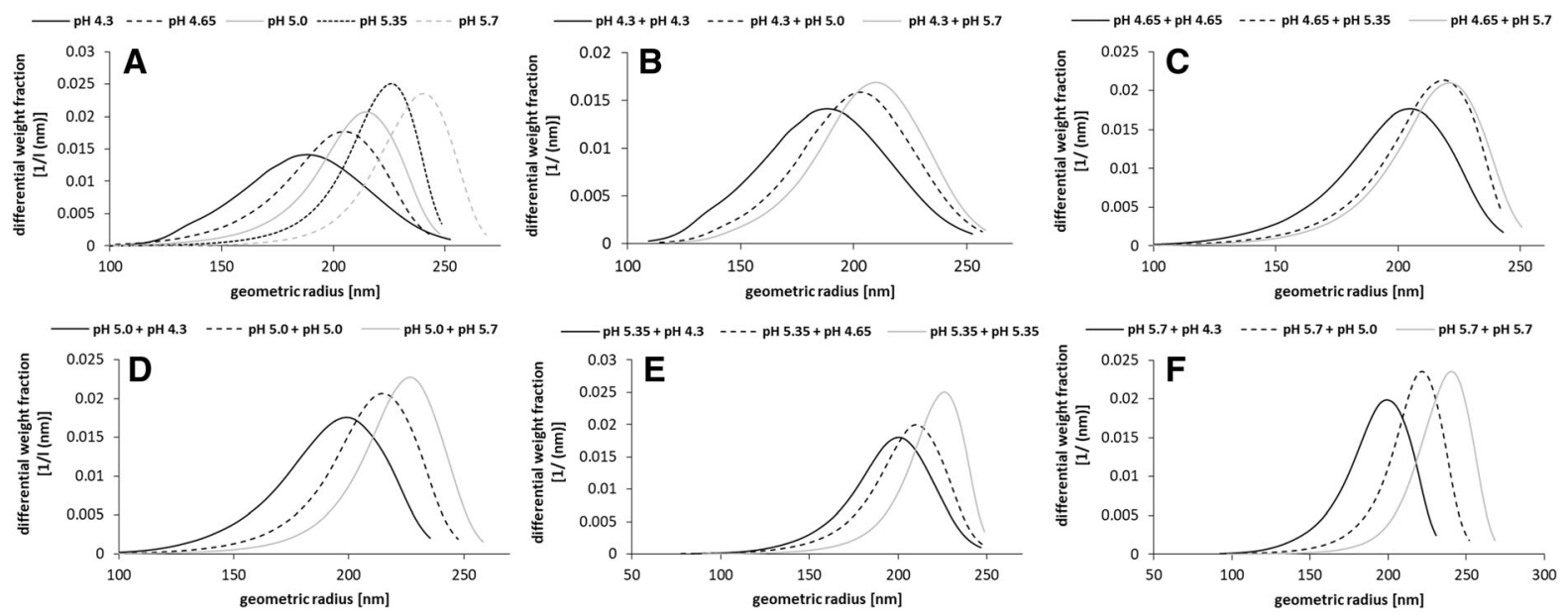

Fig. 4 Differential weight distributions of geometric radii of levans produced at different $\mathrm{pH}$. The respective radii distributions of levans produced at the $\mathrm{pH}$ of levansucrase release are depicted in (A) and in $(\mathbf{B}-\mathbf{F})$ of the three different production $\mathrm{pH}$ per release $\mathrm{pH}$ of the levansucrase: $\mathrm{pH} 4.3$ (B), 4.65 (C), 5.0 (D), $5.35(\mathbf{E})$ and $5.7(\mathbf{F})$. The experimentally determined production
$\mathrm{pH}$ values derived from the respective buffer mixtures are depicted in brackets in Fig. 1. Data are exemplarily shown for the cell culture OD $(600 \mathrm{~nm})=2.58$ of G. albidus TMW 2.1191 and were highly similar for OD 2.2 and 2.84 (data not shown), respectively 

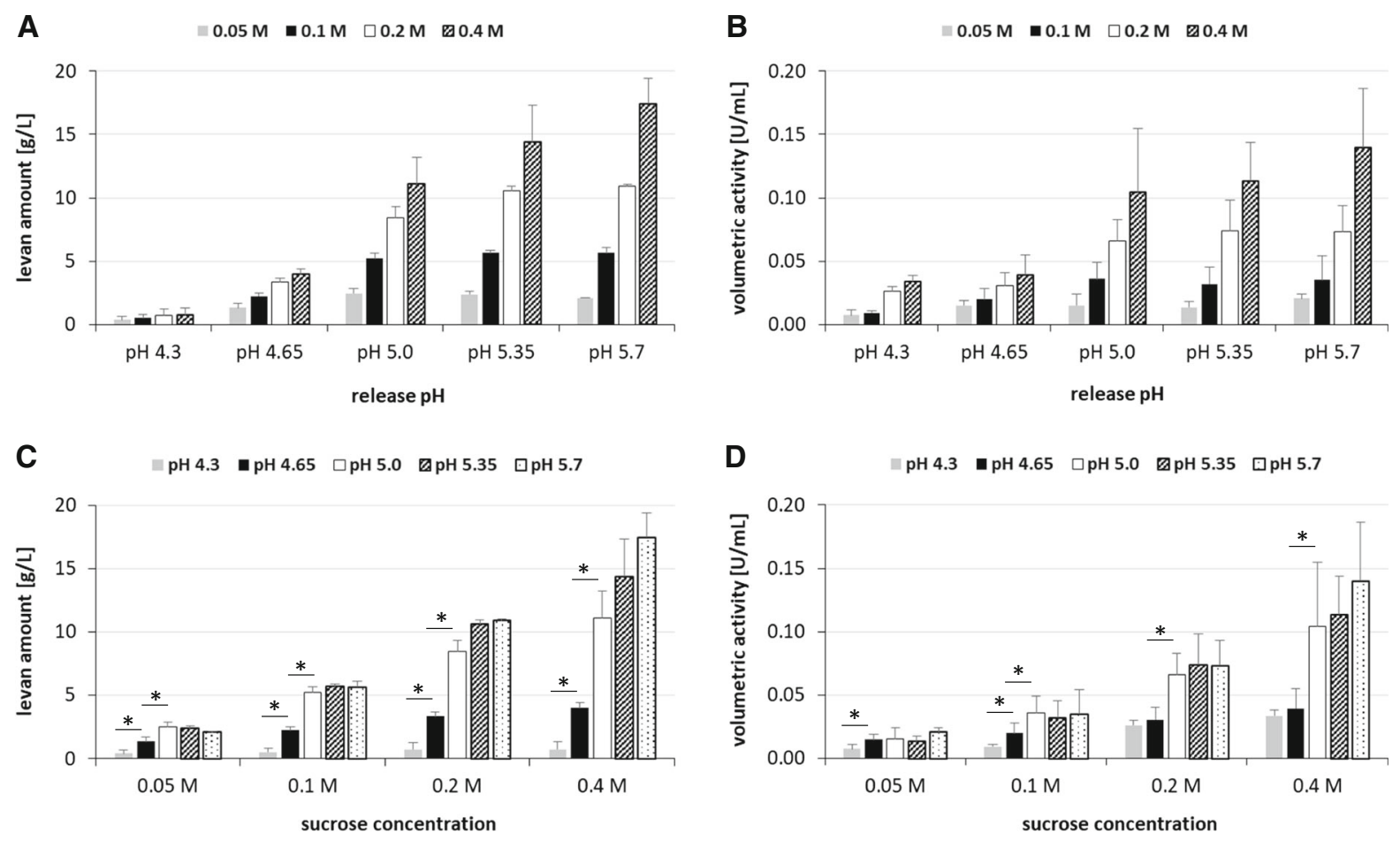

Fig. 5 Produced levan amounts $\mathbf{A}, \mathbf{C}$ at the $\mathrm{pH}$ of levansucrase release ( $\mathrm{pH} 4.3,4.65,5.0,5.35,5.7)$ using four different sucrose concentrations $(0.05,0.1,0.2,0.4 \mathrm{M})$ and the corresponding volumetric activities B, D determined after $24 \mathrm{~h}$ of levan production using three different main cultures (OD 2.63, OD 2.77, OD 3.0). Mean values $(n=3)$ including standard

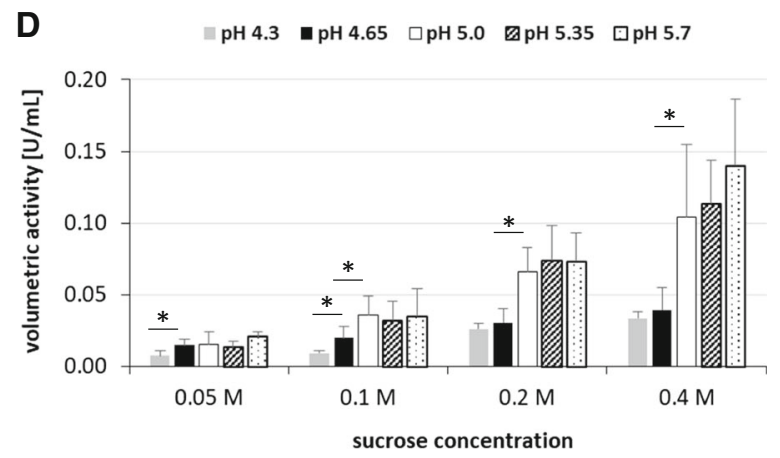

deviations (SD) were calculated from singly detemined values per cell culture and specific condition $(\mathrm{pH}$ and sucrose concentration), respectively. Stars indicate significant differences $(p<0.05)$ between the compared conditions (marked by lines)

\section{Discussion}

Previous studies revealed that the spherical high molecular weight levan molecules produced by $G$. albidus TMW 2.1191 are functionally diverse regarding their hydrocolloid and rheological properties depending on their molecular size (Hundschell et al. 2019, 2020; Jakob et al. 2012b, 2013; Ua-Arak et al. 2016, 2017b). Moreover, the production $\mathrm{pH}$ during batch fermentation is crucial for the size distributions of these levans (Hundschell et al. 2020; Ua-Arak et al. 2017a) as also shown in the present work (Figs. 4, 6). However, little is known about the influencing factors of levansucrase release as well as of levansucrase activity, both of which are crucial for the efficiency of the complex production process of polydisperse levan taking place under continuously changing conditions. By application of the developed buffer system it was confirmed that the levansucrase is constitutively

expressed by G. albidus TMW 2.1191 (without induction by its substrate sucrose) as reported for some dextransucrases secreted by water kefir LAB (Bechtner et al. 2019; Schmid et al. 2019). Higher volumetric levansucrase activities were detected in buffer supernatants at higher release $\mathrm{pH}$ (Fig. 3). The higher productivity towards levan formation at higher release $\mathrm{pH}$ could be due to comparatively higher levansucrase amounts released at higher $\mathrm{pH}$. This view is supported by the fact that the use of the same crude enzyme preparation for levan production yielded comparable levan amounts (Supplementary File S1). Moreover, higher volumetric activities were determined in buffers incubated with higher cell densities (Fig. 3) indicating that more levansucrase was released by a higher number of metabolic active cells. However, the continuous increase in productivity with rising release $\mathrm{pH}$ could not be verified in the second experimental series focusing on the impact of the 

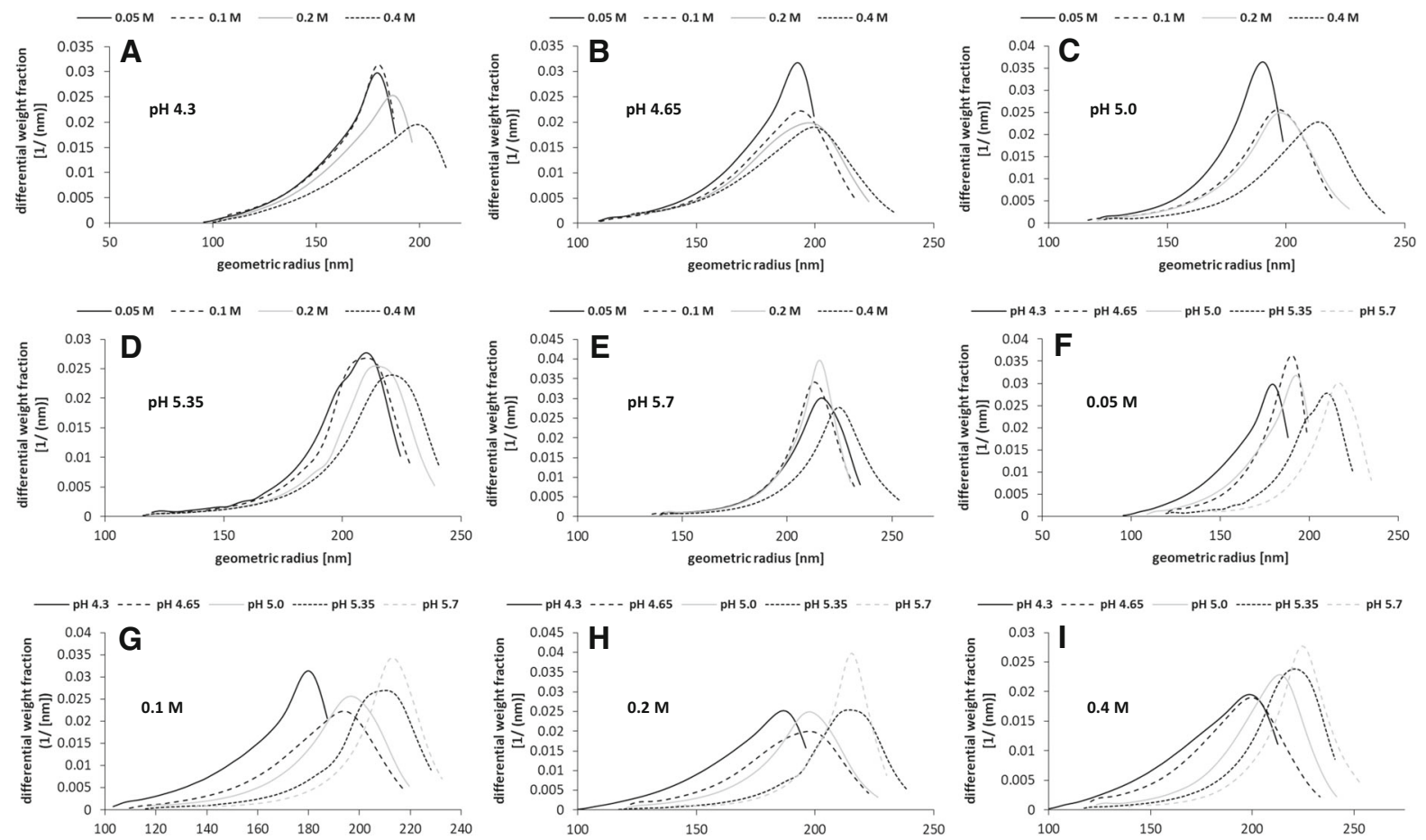

Fig. 6 Differential weight distributions of geometric radii of levans produced at different $\mathrm{pH}(\mathrm{pH} 4.3,4.65,5.0,5.35,5.7)$ and sucrose concentrations $(0.05,0.1,0.2,0.4 \mathrm{M})$. The experimentally determined production $\mathrm{pH}$ values derived from the respective buffer mixtures are depicted in brackets in Fig. 1. Data are exemplarily shown for the cell culture OD $(600 \mathrm{~nm})=$ 2.77 of G. albidus TMW 2.1191 and were highly similar for OD 2.63 and 3.0 (data not shown), respectively sucrose concentration on levan formation (3.3; Fig. 5), in which significant increases in levan amounts and volumetric overall activities could solely be observed between $\mathrm{pH} 4.3 / 4.65$ or rather $\mathrm{pH} 4.65 / 5.0$ (Fig. 5). Hence, in addition to the environmental $\mathrm{pH}$, the cell densities and/or growth phase of the levan producing cultures influenced the levan formation, as higher cell densities were applied in the second experimental series (3.3). A growth phase-dependent expression of levansucrases was also reported for the enteric bacterium Rahnella aquatilis (Seo et al. 2002), at which it has to be considered that expression and secretion/release of sucrases are in fact independent processes. For instance, the water kefir isolate Lactobacillus hordei TMW 1.1822 releases its sucroseconverting dextransucrases in similar amounts into the environment in dependence of sucrose, but independently of the applied environmental release $\mathrm{pH}$ while accumulating the dextransucrases within the cell independent of sucrose (Bechtner et al. 2019; Schmid et al. 2019). In case of Lactobacillus hordei TMW
1.1822 it was further observed that the release $\mathrm{pH}$ affects the mean activity/productivity of the dextransucrase at different $\mathrm{pH}$. This probably resulted from the concomitantly increased stability of the dextransucrase towards its denaturation at non-optimum $\mathrm{pH}$, if it had been initially recovered actively at its approximate optimum $\mathrm{pH}$. A similar feature is unlikely for the levansucrase released by G. albidus TMW 2.1191, as it appears to be comparably active and productive towards high molecular weight levan production over a broad $\mathrm{pH}$ range (Supplementary Files $1+2$ ). This suggests that this type of levansucrase is structurally adapted to changes in the extracellular $\mathrm{pH}$, which naturally result from gluconic (and acetic) acid production by G. albidus TMW 2.1191. Noticeably, Gluconobacter levansucrases are next related to those of Zymomonas mobilis (Jakob et al. 2019), whose expressed levansucrase monomers selfassemble to ordered oligomers/microfibrils at low $\mathrm{pH}$ and high ionic strength (Goldman et al. 2008). A similar structural adaptation towards a stable activity 
in the acidic environment could thus be assumed for the levansucrase of G. albidus TMW 2.1191.

In contrast to the overall glucose release and produced levan amounts, the levan sizes, which are decisive for the macromolecular properties of levan (Hundschell et al. 2019; Jakob et al. 2013), were influenced by the production pH (Figs. $4+6$ ). This could be due to different substrate saturations of the levansucrases (Fig. $6+$ Supplementary File 2), an additional expressed $\beta$-fructosidase (WP077802344) (Brandt et al. 2017; Jakob et al. 2019) and/or the possible intrinsic levanase activity (Méndez-Lorenzo et al. 2015) of the levansucrase at certain conditions. The presented experimental approach could hence be used to control and trigger the sizes of globular levan molecules. On the other hand it remains unclear if the variably influenced processes of levan biosynthesis (e.g. by a continuously changing $\mathrm{pH}$ ) can be naturally controlled by microbes for production of levan fractions, which exhibit specific properties upon occupation of sucrose-rich niches and biofilm formation. The comparable total activity of this levansucrase over a broad acidic $\mathrm{pH}$ range and release of presumably more levansucrase at higher $\mathrm{pH}$ may, however, help G. albidus TMW 2.1191 to efficiently release glucose (and fructose by hydrolysis) from sucrose. Glucose can be either directly incompletely oxidized to gluconic acid or intracellularly metabolized to pyruvate usually leading to the additional extracellular accumulation of acetic acid (Peters et al. 2013). Consequently, a stronger accumulation of acids via extracellular sucrose utilization at comparatively higher $\mathrm{pH}$ would allow quick energy generation and efficiently prevent the growth of competing, non-acid tolerant microbes. The more efficient release of constitutively expressed levansucrases by G. albidus TMW 2.1191 at higher $\mathrm{pH}$ could hence be considered as an adapted physiological feature for targeted colonization of sucrose-containing habitats.

Acknowledgements Open Access funding provided by Project DEAL. Part of this work was supported by funds of the German Federal Ministry of Food and Agriculture (BMEL) through the Federal Office of Agriculture and Food (BLE) in project 2816IP001.

\section{Compliance with ethical standards}

Conflict of interest The authors declare that there is no conflict of interest.
Open Access This article is licensed under a Creative Commons Attribution 4.0 International License, which permits use, sharing, adaptation, distribution and reproduction in any medium or format, as long as you give appropriate credit to the original author(s) and the source, provide a link to the Creative Commons licence, and indicate if changes were made. The images or other third party material in this article are included in the article's Creative Commons licence, unless indicated otherwise in a credit line to the material. If material is not included in the article's Creative Commons licence and your intended use is not permitted by statutory regulation or exceeds the permitted use, you will need to obtain permission directly from the copyright holder. To view a copy of this licence, visit http://creativecommons.org/licenses/by/4.0/.

\section{References}

Arrieta J et al (1996) Molecular characterization of the levansucrase gene from the endophytic sugarcane bacterium Acetobacter diazotrophicus SRT4. Microbiology 142:1077-1085

Bechtner J, Wefers D, Schmid J, Vogel RF, Jakob F (2019) Identification and comparison of two closely related dextransucrases released by water kefir borne Lactobacillus hordei TMW 1.1822 and Lactobacillus nagelii TMW 1.1827. Microbiology 165:956-966

Behr J, Israel L, Gänzle MG, Vogel RF (2007) Proteomic approach for characterization of hop-inducible proteins in Lactobacillus brevis. Appl Environ Microbiol 73:3300-3306

Brandt JU, Jakob F, Geissler AJ, Behr J, Vogel RF (2017) Multiple genome sequences of heteropolysaccharideforming acetic acid bacteria. Genome Announc 5:e0018517

Deppenmeier U, Ehrenreich A (2009) Physiology of acetic acid bacteria in light of the genome sequence of Gluconobacter oxydans. J Mol Microbiol Biotechnol 16:69-80

Dogsa I, Brloznik M, Stopar D, Mandic-Mulec I (2013) Exopolymer diversity and the role of levan in Bacillus subtilis biofilms. PLoS ONE 8:e62044

Fels L, Jakob F, Vogel RF, Wefers D (2018) Structural characterization of the exopolysaccharides from water kefir. Carbohydr Polym 189:296-303

Frank A, Pevzner P (2005) PepNovo: de novo peptide sequencing via probabilistic network modeling. Anal Chem 77:964-973

Frank A, Tanner S, Bafna V, Pevzner P (2005) Peptide sequence tags for fast database search in mass-spectrometry. J Proteome Res 4:1287-1295

Frank AM, Savitski MM, Nielsen ML, Zubarev RA, Pevzner PA (2007) De novo peptide sequencing and identification with precision mass spectrometry. J Proteome Res 6:114-123

Goldman D, Lavid N, Schwartz A, Shoham G, Danino D, Shoham Y (2008) Two active forms of Zymomonas mobilis levansucrase an ordered microfibril structure of the enzyme promotes levan polymerization. J Biol Chem 283:32209-32217 
Hundschell CS, Jakob F, Wagemans AM (2019) Molecular weight dependent structure and polymer density of the Exopolysaccharide Levan. arXiv preprint arXiv: 190907737

Hundschell CS, Braun A, Wefers D, Vogel RF, Jakob F (2020) Size-dependent variability in flow and viscoelastic behavior of levan produced by Gluconobacter albidus TMW 2.1191. Foods 9:192

Jakob F (2014) Novel fructans from acetic acid bacteria. Technische Universität München

Jakob F, Meißner D, Vogel RF (2012a) Comparison of novel GH 68 levansucrases of levan-overproducing Gluconobacter species. Acetic Acid Bacteria 1:e2

Jakob F, Steger S, Vogel RF (2012b) Influence of novel fructans produced by selected acetic acid bacteria on the volume and texture of wheat breads. Eur Food Res Technol 234:493-499

Jakob F, Pfaff A, Novoa-Carballal R, Rübsam H, Becker T, Vogel RF (2013) Structural analysis of fructans produced by acetic acid bacteria reveals a relation to hydrocolloid function. Carbohydr Polym 92:1234-1242

Jakob F, Quintero Y, Musacchio A, Estrada-de los Santos P, Hernández L, Vogel RF (2019) Acetic acid bacteria encode two levansucrase types of different ecological relationship. Environ Microbiol 21:4151-4165

Koczan JM, McGrath MJ, Zhao Y, Sundin GW (2009) Contribution of Erwinia amylovora exopolysaccharides amylovoran and levan to biofilm formation: implications in pathogenicity. Phytopathology 99:1237-1244

Korakli M, Pavlovic M, Gänzle MG, Vogel RF (2003) Exopolysaccharide and kestose production by Lactobacillus sanfranciscensis LTH2590. Appl Environ Microbiol 69:2073-2079

Laue H, Schenk A, Li H, Lambertsen L, Neu TR, Molin S, Ullrich MS (2006) Contribution of alginate and levan production to biofilm formation by Pseudomonas syringae. Microbiology 152:2909-2918

Méndez-Lorenzo L et al (2015) Intrinsic levanase activity of Bacillus subtilis 168 levansucrase (SacB). PLoS ONE 10:e0143394

Öner ET, Hernández L, Combie J (2016) Review of levan polysaccharide: from a century of past experiences to future prospects. Biotechnol Adv 34:827-844

Perkins DN, Pappin DJ, Creasy DM, Cottrell JS (1999) Probability-based protein identification by searching sequence databases using mass spectrometry data. ELECTROPHORESIS: Int J 20:3551-3567

Peters B et al (2013) Deletion of pyruvate decarboxylase by a new method for efficient markerless gene deletions in Gluconobacter oxydans. Appl Microbiol Biotechnol 97:2521-2530

Schmid J, Bechtner J, Vogel RF, Jakob F (2019) A systematic approach to study the $\mathrm{pH}$-dependent release, productivity and product specificity of dextransucrases. Microb Cell Fact 18:1-8

Semjonovs P, Shakirova L, Treimane R, Shvirksts K, Auzina L, Cleenwerck I, Zikmanis P (2016) Production of extracellular fructans by Gluconobacter nephelii P1464. Lett Appl Microbiol 62:145-152

Seo J-W et al (2002) Molecular characterization of the growth phase-dependent expression of the 1srA gene, encoding levansucrase of Rahnella aquatilis. J Bacteriol 184:5862-5870

Shih I-L, Yu Y-T, Shieh C-J, Hsieh C-Y (2005) Selective production and characterization of levan by Bacillus subtilis (Natto) Takahashi. J Agric Food Chem 53:8211-8215

Spriestersbach A, Kubicek J, Schaefer F, Block H, Maertens B (2015) Purification of His-tagged proteins. In: Methods in enzymology, vol 559. Elsevier, pp 1-15

Támbara Y, Hormaza JV, Pérez C, León A, Arrieta J, Hernández L (1999) Structural analysis and optimised production of fructo-oligosaccharides by levansucrase from Acetobacter diazotrophicus SRT4. Biotech Lett 21:117-121

Tieking M, Gänzle MG (2005) Exopolysaccharides from cerealassociated lactobacilli. Trends Food Sci Technol 16:79-84

Tieking M, Ehrmann MA, Vogel RF, Gänzle MG (2005) Molecular and functional characterization of a levansucrase from the sourdough isolate Lactobacillus sanfranciscensis TMW 1.392. Appl Microbiol Biotechnol 66:655-663

Ua-Arak T, Jakob F, Vogel RF (2016) Characterization of growth and exopolysaccharide production of selected acetic acid bacteria in buckwheat sourdoughs. Int J Food Microbiol 239:103-112

Ua-Arak T, Jakob F, Vogel RF (2017a) Fermentation pH modulates the size distributions and functional properties of Gluconobacter albidus TMW 2.1191 levan. Frontiers Microbiol 8:807

Ua-Arak T, Jakob F, Vogel RF (2017b) Influence of levanproducing acetic acid bacteria on buckwheat-sourdough breads. Food Microbiol 65:95-104

Velázquez-Hernández M, Baizabal-Aguirre V, Bravo-Patiño A, Cajero-Juárez M, Chávez-Moctezuma M, Valdez-Alarcón J (2009) Microbial fructosyltransferases and the role of fructans. J Appl Microbiol 106:1763-1778

Xu Q, Yajima T, Li W, Saito K, Ohshima Y, Yoshikai Y (2006) Levan ( $\beta$-2, 6-fructan), a major fraction of fermented soybean mucilage, displays immunostimulating properties via Toll-like receptor 4 signalling: induction of interleukin-12 production and suppression of T-helper type 2 response and immunoglobulin E production. Clin Exp Allergy 36:94-101

Publisher's Note Springer Nature remains neutral with regard to jurisdictional claims in published maps and institutional affiliations. 